\title{
The assessment of twin pregnancies delivered in our clinic: three-year experience
}

\author{
Cengiz Şanlı (D), Salih Burçin Kavak (D), Melike Aslan (D), Ebru Çelik Kavak (D), \\ İbrahim Batmaz (D), Gülay Bulu \\ Department of Gynecology and Obstetrics, Faculty of Medicine, Firat University, Elazığ, Turkey
}

\begin{abstract}
Objective: Twin pregnancies constitute $1-2 \%$ of all pregnancies. With the recent developments in assisted reproductive technologies, the incidence of multiple pregnancy has increased. Preterm labor is held responsible for the poor neonatal outcomes primarily. In our study, we aimed to assess fetal-maternal outcomes of twin pregnancies seen in our clinic.

Methods: One hundred and thirty twin pregnancy cases out of 4241 pregnant women who delivered in our clinic between 01.01.2017 and 01.01.2020 were included in the study. The labor records of the patients were reviewed retrospectively and their data for age, week of gestation, delivery type, birth weight, fetal sex, chorionicity characteristics and laboratory parameters were recorded. Definitive statistics and SPSS 21.0 for statistical analyses were used to evaluate the data obtained from the study. The data were presented as mean \pm SD (standard deviation)

Results: The incidence of twin pregnancy was found 3\%. In the ultrasonographic imaging evaluated during diagnosis, $27.7 \%$ of the cases were monochorionic and $72 \%$ of them were dichorionic. Of the pregnant women, $12.3 \%$ were at term and $87.7 \%$ were at preterm period. When the preterm fetuses were evaluated, $37.7 \%$ of 114 preterm fetuses were delivered at late preterm period, $29.2 \%$ of them at mid-preterm period and $20.8 \%$ at premature preterm period. The rates of treatment pregnancy (pregnancy provided by ovulation induction and assisted reproductive technologies) and spontaneous twin pregnancy were $20 \%$ and $80 \%$, respectively. Mean maternal age was found 31.3. When evaluated in terms of maternal morbidity, preterm labor and premature rupture of membrane were the most common problems. Mean newborn weight was $1832 \mathrm{~g}$ and $59.3 \%$ of the newborns had low birth weight and $21.8 \%$ of them had very low birth weight. While one fetus had transverse presentation in $12.5 \%$ of the patients, at least one fetus had breech presentation in $53.1 \%$ of the cases and $34.4 \%$ of the cases had head-head presentation.

Conclusion: Twin pregnancies are characterized by the increased feto-maternal risks. Therefore, both antenatal and intrapartum management should be maintained diligently.
\end{abstract}

Keywords: Twin pregnancy, complication.

\section{Özet: Kliniğimizde doğum yapan ikiz gebeliklerin değerlendirilmesi: Üç yıllık deneyim}

Amaç: İkiz gebelikler tüm gebeliklerin \% 1-2'sini oluşturmaktadır. Son zamanlarda yardımla üreme tekniklerinin yaygınlaşmasıyla beraber çoğul gebelik insidansında artış izlenmiştir. Kötü neonatal sonuçlardan temel olarak erken doğum eylemi sorumlu tutulmaktadır. Bu çalışmada kliniğimizde görülen ikiz gebeliklerin fetalmaternal sonuçlarını değerlendirmeyi amaçladık.

Yöntem: Kliniğimizde 01.01.2017 - 01.01.2020 tarihleri arasında doğum yapan toplam 4241 gebe arasında yer alan 130 ikiz gebe çalışmaya dâhil edildi. Hastaların doğum kayıtları retrospektif olarak incelenerek yaş, gebelik haftası, doğum şekli, doğum ağırlığı, fetal cinsiyetler, koryonisite özellikleri, hastaların laboratuvar parametreleri kayıt altına alındı. Calışmada elde edilen verilerin değerlendirilmesinde, tanımlayıcı istatistik, istatistiksel analizler için SPSS 21.0 programı kullanıldı. Veriler ortalama \pm SS (standart sapma) olarak belirtildi.

Bulgular: İkiz gebelik sıklığ $\% 3$ olarak tespit edildi. Tanı anında değerlendirilen ultrasonografik görüntülemede olguların \%27.7’ monokoryonik ve $\% 72$ 'si ise dikoryonik olarak belirlendi. Gebelerin \%12.3'ü term ve \%87.7'si preterm dönemde idi. Preterm fetüsler değerlendirildiğinde 114 preterm fetüsün \%37.7'si geç preterm, \%29.2'si orta preterm ve \%20.8'i erken preterm doğum idi. Tedavi gebeliği (ovulasyon indüksiyonu ve yardımla üreme teknikleri ile sağlanmıs gebelik) oranı \%20 ve spontan ikiz gebelik oranı $\% 80$ olarak saptandi. Ortalama maternal yaş 31.3 olarak belirlendi. Maternal morbidite açısından incelendiğinde anemi, erken doğum eylemi ve erken membran rüptürü en sik problemler olarak izlendi. Ortalama bebek ağırlığ $1832 \mathrm{~g}$ olarak belirlendi ve bebeklerin \%59.3'ü düşük doğum ağırlıklı bebek, \%21.8'i çok düşük ağırlıklı bebek olarak değerlendirildi. Hastaların \%12.5'inde bir fetüs transvers prezentasyona sahip iken, \%53.1 olguda ise en az bir fetüs makat prezentasyonunda idi ve \%34.4 olgu ise baş-baş prezentasyonuna sahip idi.

Sonuç: İkiz gebelikler artmış feto-maternal risklerle karakterizedir. Bu nedenle hem antenatal hem de intrapartum yönetim titizlikle yürütülmelidir.

Anahtar sözcükler: İkiz gebelik, komplikasyon.

Correspondence: Salih Burçin Kavak, MD. Department of Gynecology and Obstetrics, Faculty of Medicine, Frrat University, Elazığ, Turkey. e-mail: burcinkavak1@gmail.com / Received: June 23, 2020; Accepted: July 27, 2020

Please cite this article as: Şanlı C, Kavak SB, Aslan M, Çelik Kavak E, Batmaz İ, Bulu G. The assessment of twin pregnancies delivered in our clinic: three-year experience. Perinatal Journal 2020;28(3):170-175. doi:10.2399/prn.20.0283005 


\section{Introduction}

In the light of classical information, it is seen that twin pregnancies constitutes $1-2 \%$ of all pregnancies. ${ }^{[1]}$ However, a significant increase in the incidence of multiple pregnancy has been observed together with the common use of ovulation induction and assisted reproductive techniques in the recent years. ${ }^{[2,3]}$ The incidence of multiple pregnancy in a population can be classically calculated as twin pregnancies $1 / \mathrm{n}$, triple pregnancies $1 / \mathrm{n}^{2}$, and quadruplet pregnancies $1 / \mathrm{n}^{3} \cdot{ }^{[4]}$

Multiple pregnancies are considered risky pregnancies due to high maternal and perinatal morbidity rates. In multiple pregnancies, preterm labor is held responsible for the poor neonatal outcomes primarily. Preterm labor is seen $7-10$ time more in multiples pregnancies than singleton pregnancies. This was explained by factors such as the increased uterine tension, low blood build up, mechanical pressure on cervix and premature rupture of membrane. ${ }^{[5]}$ In addition, the incidences of the complications such as gestational hypertension, placenta previa, antenatal and intrapartum bleeding, hyperemesis gravidarum and premature rupture of membrane also increased. ${ }^{[6]}$

In general, twin pregnancies constitute about $10-12 \%$ of perinatal mortality. ${ }^{[7]}$ Intrauterine death and newborn death rates are higher compared to singleton pregnancies. ${ }^{[8]}$ Although the perinatal mortality rate decreased throughout the years, the prematurity risk in multiple pregnancies have not changed within last $20-30$ years. $^{[9]}$

In our study, we aimed to evaluate the maternal and fetal outcomes of twin pregnancies, which are the reasons of severe fetal and maternal morbidity and mortality, that delivered within last 3 years in our center.

\section{Methods}

One hundred and thirty pregnancy cases were found among 4241 pregnant women who delivered in our clinic between 01.01.2017 and 01.01.2020. The records of the patients were reviewed retrospectively, and their data for age, week of gestation, delivery type, birth weight, fetal sex, chorionicity characteristics and laboratory parameters were recorded. Maternal age was accepted as the age during labor. The week of gestation was determined according to the last menstrual period for those who had regular menstruation, and according to the fetal crown-rump length for those who had irregular menstruation and conceived by in vitro fertilization.

When evaluating the data obtained in the study, SPSS 21.0 (SPSS Inc., Chicago, IL, USA) was used for statistical analyses. The data were presented as mean \pm SD (standard deviation). The descriptive statistics were used in the data analysis, and $\mathrm{p}<0.05$ was considered statistically significant.

\section{Results}

The incidence of twin pregnancy was 3\% (130/4241) in our study. It was seen in the ultrasonographic imaging performed during diagnosis that $72.3 \%$ of the cases were dichorionic diamniotic (94 cases), 26.2\% of them were monochorionic diamniotic (34 cases), and $1.5 \%$ of them were monochorionic monoamniotic ( 2 cases). Of the pregnant women, $12.3 \%$ (16 cases) were at term and $87.7 \%$ (114 cases) were at preterm period. All term cases were between 37 and 39 weeks of gestation and they were evaluated as early term. When preterm fetus cases were evaluated, it was found that $49(37.7 \%)$ cases of 114 preterm fetuses were late preterm (34-36 weeks and 6 days), 27 (20.8\%) cases were mid-preterm (32-33 weeks and 6 days), and 38 (29.2\%) cases were early preterm labors (24-32 weeks) (Fig. 1).

In our study, the rate of treatment pregnancy (pregnancies by ovulation induction and assisted reproductive technologies) was $20 \%$ (26 cases) and the rate of spontaneous twin pregnancy was $80 \%$ (104 cases). Of the treat-

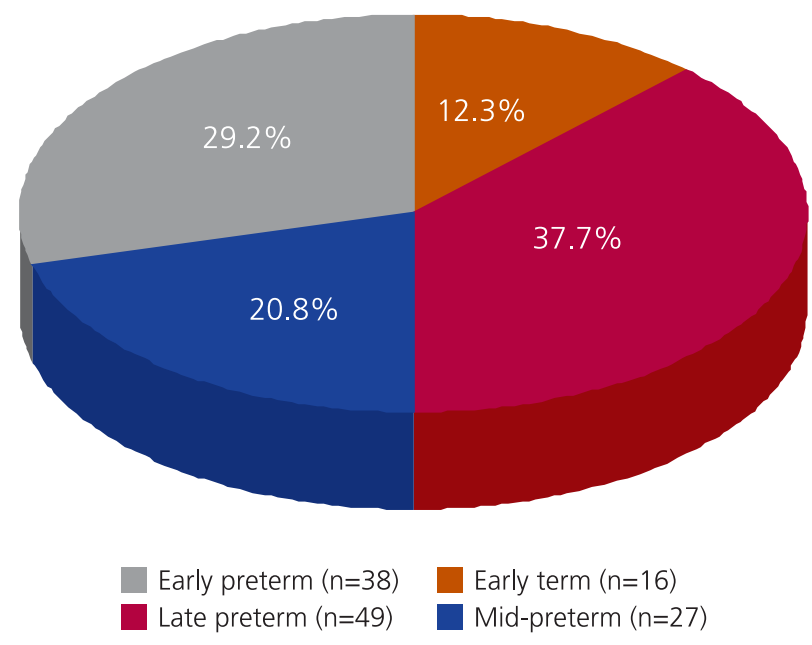

Fig. 1. The gestational ages of the cases at labor. 
Table 1. The distribution of labor and maternal ages according to the treatment and spontaneous pregnancy characteristics.

\begin{tabular}{|c|c|c|c|c|c|c|c|c|}
\hline \multirow[b]{2}{*}{ Characteristics } & \multicolumn{4}{|c|}{$<35$ years old $(n=66)$} & \multicolumn{4}{|c|}{$>35$ years old $(n=64)$} \\
\hline & $\begin{array}{l}24-31^{6} \\
\text { weeks }\end{array}$ & $\begin{array}{l}32-33^{6} \\
\text { weeks }\end{array}$ & $\begin{array}{l}34-36^{6} \\
\text { weeks }\end{array}$ & $\begin{array}{l}\text { 37-39 } \\
\text { weeks }\end{array}$ & $\begin{array}{l}24-31^{6} \\
\text { weeks }\end{array}$ & $\begin{array}{l}32-33^{6} \\
\text { weeks }\end{array}$ & $\begin{array}{l}34-36^{6} \\
\text { weeks }\end{array}$ & $\begin{array}{l}\text { 37-39 } \\
\text { weeks }\end{array}$ \\
\hline Treatment pregnancy (IUI, IVF) (n) & 4 & 3 & 6 & 5 & 2 & 1 & 2 & 3 \\
\hline Spontaneous pregnancy (n) & 13 & 8 & 23 & 4 & 19 & 15 & 18 & 4 \\
\hline
\end{tabular}

ment pregnancies, 8 were early term and 18 were preterm labor ( $<37$ weeks) while 6 of them were early preterm. Of the spontaneous pregnancies, 8 were early term (37-39 weeks) and 96 were preterm labor. Thirty-two of the preterm labors were early preterm, 23 of them were midpreterm, and 41 of them were late preterm (Table 1).

While 66 cases were younger than 35 years old, 64 cases were older than 35 years old. When weeks of gestation were evaluated according to maternal age, we found that there was no significant difference. Mean maternal age of our patients was 31.3 (range: 17-45). While our 45 cases were having their first pregnancy, 37 cases were primiparous pregnancy and 48 cases were multiparous pregnancy. Forty-one cases delivered by cesarean section due to recurrent cesarean section, and first baby was delivered by vaginal labor in 2 cases while the second baby was delivered by cesarean section due to cord prolapse and change of presentation. One case underwent hysterectomy due to invasion anomaly.

When the cases were evaluated in terms of maternal morbidity, preterm labor (41 cases, $31.5 \%$ ), anemia (27 cases, $20.7 \%$ ), preterm premature rupture of membrane (34 cases, 26.2\%) and selective intrauterine growth restriction (12 cases, 9.2\%) were found to be the most common problems. Moreover, preeclampsia, gestational diabetes and intrahepatic cholestasis of pregnancy were observed in $8(6.2 \%), 8(6.2 \%)$ and $7(5.4 \%)$ cases, respectively. Twin-to-twin transfusion was found in 3 cases $(2.3 \%)$ (Tables 2 and 3); while it was found out that two of these cases underwent laser ablation treatment in an external center, one case was referred to our clinic from an external center at 26 weeks and the pregnancy was ended by emergency cesarean section.

When newborn's Apgar scores were evaluated, it was observed that 1 -minute $(\mathrm{p}=0.01)$ and 5 -minute $(\mathrm{p}<0.01)$ Apgar scores increased significantly. Mean birth weight was found $1832 \mathrm{~g}$, and $59.3 \%$ of the newborns had low birth weight $(<2500 \mathrm{~g})$ and $21.8 \%$ of them had very low birth weight $(<1500 \mathrm{~g})$. When Apgar scores were assessed according to newborn weights, it was observed that 1minute $(\mathrm{p}=0.02)$ and 5-minute $(\mathrm{p}=0.01)$ Apgar scores increased significantly.

While one fetus in $12.5 \%$ of the patients $(n=16)$ had transverse presentation, at least one fetus was in breech presentation $(31.3 \%$ of them were breech-breech, and $21.8 \%$ of them were head-breech) in $53.1 \%$ of the cases $(n=69)$. All these cases delivered by the cesarean section. $34.4 \%$ of the cases $(n=45)$ were head-head presentation. Thirty-three cases with head-head presentation were delivered by the cesarean section due to placenta previa (3 cases), severe preeclampsia (4 cases), early preterm labor (13 cases), selective intrauterine growth restriction ( 2 cases) and family anxiety (11 cases). Twelve cases delivered vaginally.

Table 2. The complications seen in the preterm cases.

\begin{tabular}{lc}
\hline Complication* & $\mathbf{n}(\mathbf{\%})$ \\
\hline Preterm labor & $41(31.5 \%)$ \\
\hline Anemia & $27(20.7 \%)$ \\
\hline Premature preterm rupture of membrane & $34(26.2 \%)$ \\
\hline Selective intrauterine growth restriction & $12(9.2 \%)$ \\
\hline Preeclampsia & $8(6.2 \%)$ \\
\hline Gestational diabetes & $8(6.2 \%)$ \\
\hline Pregestational diabetes & $1(0.8 \%)$ \\
\hline Hepatic cholestasis of pregnancy & $7(5.4 \%)$ \\
\hline Twin-to-twin transfusion syndrome & $3(2.3 \%)$ \\
\hline Placenta previa & $129.2 \%$ \\
\hline
\end{tabular}

*More than one complication was observed in some cases.

Table 3. The complications seen in the cases at term.

\begin{tabular}{lc} 
Complication & $\mathbf{n}(\mathbf{\%})$ \\
\hline No complication & $7(5.4 \%)$ \\
\hline Premature rupture of membrane & $3(2.3 \%)$ \\
\hline Preeclampsia & $4(3.0 \%)$ \\
\hline Gestational diabetes & $2(1.5 \%)$ \\
\hline
\end{tabular}




\section{Discussion}

Multiple pregnancies constitute 1-2\% of all pregnancies, and they are high-risk pregnancies due to the increased feto-maternal morbidity and mortality. Together with the prevalent use of ovulation induction and assisted reproductive techniques, an increase up to $3 \%$ was observed in the incidence of multiple pregnancy. ${ }^{[1-3]}$ Similarly, we found the incidence of multiple pregnancy $3 \%$ in our study. Of them, $20 \%$ were treatment pregnancy, and $80 \%$ were spontaneous multiple pregnancy.

The most common obstetric complication in the multiple pregnancies is preterm labor; the preterm labor is seen more commonly in multiple pregnancies compared to singleton pregnancies. This was associated with the factors such as the increased uterine tension, low blood build up, mechanical pressure on cervix and premature rupture of membrane. ${ }^{[5]}$ Despite the decreasing perinatal mortality rates in the recent years, the prematurity risk and incidence has not decreased in multiple pregnancies. ${ }^{[9]}$ Ülkümen et al. reported the rate of labors at and before 37 weeks in twins $95 \%$, and Gül et al. reported premature labor rate $73 \%$ in their study. ${ }^{[10,11]}$ We found prematurity incidence in twins $78 \%$ similar to the literature. Twin pregnancies complete lung development at 37 weeks, triples pregnancies at 31-33 weeks and quadruplet pregnancies at 29 weeks. ${ }^{[12]}$ As lung maturation is usually completed at 31-32 weeks in twin pregnancies, perinatal morbidity and mortality rates are high in labors before these weeks, and the prematurity-related complications decrease after these weeks. ${ }^{[12]}$ Gül et al. reported that they found a significant correlation between low Apgar scores and prematurity and immaturity in their study. ${ }^{[11]}$ Similarly, we found a statistically significant correlation between delivery week and 1minute and 5-minute Apgar scores ( $\mathrm{p}<0.005)$.

Some different approaches have been suggested to prevent the complications seen in multiple pregnancies. One of the generally-accepted opinions is to limit the number of embryo, which is transferred during in vitro fertilization procedure, with two. This method results in the reduction of pre- and postnatal complications of gestation without affecting pregnancy period and fetal development. ${ }^{[13]}$ Another method is the multifetal reduction. Reducing twins to single fetus decreases twin-related complications, but there is still no full consensus on this method. This method is recommended in pregnancies with three or more fetuses. ${ }^{[14]}$
In terms of birth weight, the newborns which weigh $1500 \mathrm{~g}$ or less are considered as newborns with very low birth weight and those which weigh between $1500 \mathrm{~g}$ and $2500 \mathrm{~g}$ are considered as newborns with low birth weight. In a twin-pregnancy study published in Turkey in 2013, the rate of newborns with very low birth weight was reported $12.7 \%$ and the rate of newborns with low birth weight was reported $51.1 \% \cdot{ }^{[10]}$ In our study, mean twin weight was $1832 \mathrm{~g}$, and the rates of newborns with very low birth weight and low birth weight were $21.8 \%$ and $59.3 \%$, respectively. In a multiple pregnancy study conducted in Turkey in 2013, the rates of very low birth weight and low birth weight were reported $55-65 \%$ and $17-20 \%$, respectively. ${ }^{[15]}$

Although there is an increase in the maternal blood volume in twin pregnancies, the anemia of iron and folic acid deficiency is a common condition. Blood transfusion is required when hemoglobin level is below $8 \mathrm{~g} / \mathrm{dl} .^{[1,1,1]}$ The anemia rate in the multiple pregnancy study of Gül et al. in 1998 was reported 30\% similar to our study. ${ }^{[11}$ There were 2 pregnant women among anemic patients in our study which required blood transfusion.

Although there are publications asserting that there is a risk of increased gestational diabetes mellitus in multiple pregnancies compared to the singleton pregnancies, there are also publications which could not find a significant correlation. ${ }^{[18]}$ In our study, the GDM rate was $6 \%$ in line with those results. Kazandi et al. reported in their study conducted in 2011 that the preeclampsia incidence was $7 \%$, cholestasis was $4 \%$ and premature rupture of membrane was $20 \% .^{[19]}$ Similarly, we found that preeclampsia was $6 \%$, cholestasis was $5 \%$ and premature rupture of membrane was $26 \%$ in our study.

The growth restriction was reported $8 \%$ in fetuses of twin pregnancies. ${ }^{[20]} \mathrm{We}$ similarly found growth restriction in 12 cases $(9.2 \%)$.

Twin pregnancy is diamniotic dichorionic (two amniotic sac and two placentas) if division occurs in zygote within the first 3 days after fertilization in twin pregnancies, monochorionic diamniotic (two amniotic sac and one placenta) if division occurs between 4 and 8 days, and monochorionic monoamniotic (one amniotic sac and one placenta) if division occurs after 8 days. Conjoined twins are observed in divisions occurring after 14 days. ${ }^{[21]}$ There are publications emphasizing that neonatal morbidity increases prominently in monochorionic twin pregnancies and therefore chorionicity should be considered in 
the first trimester. ${ }^{[2]}$ When we reviewed the first trimester ultrasound images of the pregnant women included in our study, we found that the chorionicity of less than $50 \%$ of the cases was observed during early weeks of gestation. In our study, we found the rate of monochorionic pregnancy rate $27 \%$ in the ultrasonography examination performed during diagnosis, and observed premature rupture of membrane 3 times higher in these cases compared to dichorionic pregnancies. The absence of proper comparison of chorionicity and neonatal outcomes as chorionicity was not specified in the first trimester ultrasonography examinations of the most of the patients is one of the limitations of our study.

There are many maternal and fetal factors that should be paid attention in terms of delivery type in twin pregnancies. ${ }^{[23]}$ The fetal characteristics of the patients such as parity, previous delivery type, concurrent diseases, week of gestation and growth restriction should be taken into consideration. We prefer vaginal delivery in pregnancies with head-head presentation, and our 12 cases which delivered vaginally had head-head presentation. In addition, our 2 cases with head-head presentation delivered by cesarean section due to the cord prolapse and change of presentation to breech in second baby. We observed malpresentation (transverse, headbreech or breach-breach presentation) in $65.6 \%$ of our cases. We believe that such high rate of presentation anomaly results from the fact that our hospital is a reference center. In addition, the reasons such as increasing malpractice concerns and family anxiety in recent years seem to cause a decrease in the incidence of vaginal delivery. While there are studies arguing that cesarean section would reduce labor trauma due to high rates of malpresentation and prematurity in twin pregnancies and that there would not be a significant increase in cesarean section operations as twin pregnancies constitute only about $1 \%$ of all pregnancies, there are also other studies claiming that recurrent cesarean section rate would increase with the increase in maternal mortality and morbidity and longer hospitalization periods, and that fetal morbidity and mortality rates would not be higher by vaginal delivery in appropriate cases. ${ }^{[24]}$ During the study period, the our cesarean section rate in multiple pregnancies was $90.7 \%$. We associate the increased rate of cesarean section with the referral of complicated patients to our hospital as it is a tertiary center, the intensity of patients who are anxious socio-culturally, and the tendency of treatment pregnancies to delivery by cesare- an section. In terms of indications, presentation anomalies were the most common cesarean section indication. The locking risk of fetuses in non-vertex-vertex presentation was reported $0.1 \%$ and its mortality rate was reported 31\%. ${ }^{[25]}$ Our 41 (31.5\%) cases delivered by cesarean section due to recurrent cesarean section.

\section{Conclusion}

Twin pregnancies are characterized by the increased feto-maternal risks. Therefore, both antenatal and intrapartum management should be maintained diligently.

Conflicts of Interest: No conflicts declared.

\section{References}

1. Jones JM, Sbarra AJ, Cetrulo CL. Antepartum management of twin gestation. Clin Obstet Gynecol 1990;33:32-41. [PubMed] [CrossRef]

2. Imaizumi Y. A comparative study of twinning and triplet rates in 17 countries 1992-1996. Acta Genet Med Gemellol (Roma) 1998;47:10-14. [PubMed] [CrossRef]

3. Baxi A, Kaushal M. Outcome of twin pregnancies conceived after assisted reproductive techniques. J Hum Reprod Sci 2008;1:25-8. [PubMed] [CrossRef]

4. Benirschke K. Multiple gestation: the biology of twinning. In: Resnik R, Creasy RK, Iams JD, Lockwood CJ, Moore T, Greene MF, editors. Creasy and Resnik's maternal-fetal medicine: Principles and practice. 7th ed. Philadelphia, PA: Elsevier Saunders; 2014. p. 53-65.

5. American College of Obstetricans and Gynecologist. ACOG educational bulletin. Special problems of multiple gestation. Number 253, November 1998 (Replaces Number 131, August 1989). Int J Gynaecol Obstet 1999;64:323-33. [PubMed]

6. Wen SW, Demissie K, Yang Q, Walker MC. Maternal morbidity and obstetric complications in triplet pregnancies and quadruplet and higher-order multiple pregnancies Am J Obstet Gynecol 2004;191:254-8. [PubMed] [CrossRef]

7. Sivaslı E, Tekinalp G. Çoğul gebelikler. Hacettepe Tıp Dergisi 2004;35:154-9.

8. Mun S, Taner CE, Oztekin M, Celimli FH. İkiz eşinin intrauterin ölümü. Dokuz Eylül Üniversitesi Tıp Fakültesi Dergisi 2005;19:31-6.

9. Aköz İ, Benk D, Ayas S, Yakut Y. 2000-2003 Yılları arasındaki çoğul gebeliklerde obstetrik ve perinatal sonuçlarımız. Kartal Eğitim ve Araştırma Hastanesi Tıp Dergisi 2003;9:180-3.

10. Artunç Ülkümen B, Pala HG, Çalık E, Koyuncu FM. İkiz gebeliklerde fetal ve maternal sonuçların değerlendirilmesi. Dokuz Eylül Üniversitesi Tıp Fakültesi Dergisi 2013;3:123-8.

11. Gül T, Sarı A, Kara IH, Karaca M, Demir M, Cerden A. Kliniğimizde son iki yılda doğum yapan çoğul gebeliklerin değerlendirilmesi. Perinatoloji Dergisi 1998;6:70-3. 
12. Brecht JL, Tomich PG. The maternal and neonatal outcome of triplet gestations. Am J Obstet Gynecol 1996;174:1551-6. [PubMed] [CrossRef]

13. Van der Straeten FM, De Ketelaere K, Temmerman M. Delayed interval delivery in multiple pregnancies. Eur J Obstet Gynecol Reprod Biol 2001;99:85-9. [PubMed] [CrossRef]

14. Evans MI, Krivchenia EL, Gelber SE, Wapner RJ. Selective reduction. Clin Perinatol 2003;30:103-11. [PubMed] [CrossRef]

15. Vural H. Tersiyer bir merkezde doğum yapan çoğul gebeliklerin retrospektif analizi. Tipta uzmanlık tezi, Dicle Üniversitesi Tıp Fakültesi, Diyarbakır, 2013. Available from: https://tez.yok.gov.tr/UlusalTezMerkezi/tezSorguSonuc Yeni.jsp

16. Cruz AC. İkiz gebelik. Zuspan FB, editor. Current therapy in obstetrics and gynecology. 4th ed. (Çev. ed. Güner H). Ankara: Atlas Yayıncilik; 1995. p. 391-7.

17. Davis EV. Anemia. In: Gleicher N, editor. Principles and practice of medical therapy in pregnancy. New York, NY: Appleton\&Lange; 1992. p. 28-969.

18. Madazlı R. Çoğul gebelik komplikasyonları. In: Madazlı R, editor. Çoğul gebelik. İstanbul: Scala Yayıncılık ve Tanıtım; 2004. p. 154.
19. Kazandı M, Turan V. Multiple pregnancies and their complications. Turkish Journal of Obstetrics and Gynecology 2011; 8:21-4. [CrossRef]

20. Sümer D, Çetin M, Yenicesu A.G, Yanık A. Spontan ve IVF ikiz gebeliklerin obstetrik ve perinatal sonuçlarının karşılaştırılmasi. Cumhuriyet Tip Dergisi 2013;35:526-31. [CrossRef]

21. Bush MC, Pernoll ML. Multiple gestation. In: DeCherney AH, Nathan L, Laufer N, Roman A, editors. Current diagnosis and treatment obstetrics and gynecology. 11th ed. New York, NY: McGraw-Hill; 2013. p. 301-9.

22. Yıldırım G, Gül A, Aslan H, Erol O, Güngördük K, Ceylan Y. The effect of the chorionicity on the neonatal and maternal outcomes in twin pregnancies. Turkish Journal of Obstetrics and Gynecology 2007;4:178-3.

23. Veccicina M, Major C, Morgan MA. Labor and delivery management of the multile gestations. Obstet Gynecol Clin North Am 1995;22:235-46. [PubMed]

24. Trofatter KF. Twin pregnancy: management of delivery. Clin Perinatol 1988;15:93-106. [PubMed]

25. Warenski JC, Kochenour NK. Intrapatum management of twin gestation. Clin Perinatol 1989:16:889-97. [PubMed]

Bu makalenin kullanım izni Creative Commons Attribution-NoCommercial-NoDerivs 3.0 Unported (CC BY-NC-ND3.0) lisansı aracılığıla bedelsiz sunulmaktadır. / This work is licensed under the Creative Commons Attribution-NonCommercial-NoDerivs 3.0 Unported (CC BY-NC-ND3.0) License. To view a copy of this license, visit http://creativecommons.org/licenses/by-nc-nd/3.0/ or send a letter to Creative Commons, PO Box 1866 , Mountain View, CA 94042, USA. 